\title{
First description of algal mutualistic endosymbiosis in a black coral (Anthozoa: Antipatharia)
}

\author{
Marzia Bo ${ }^{1, *}$, Andrew C. Baker ${ }^{2,3}$, Elda Gaino ${ }^{4}$, Herman H. Wirshing ${ }^{2}$, \\ Francesca Scoccia ${ }^{4}$, Giorgio Bavestrello ${ }^{1}$ \\ ${ }^{1}$ Dipartimento di Scienze del Mare, Università Politecnica delle Marche, Ancona 60131, Italy \\ ${ }^{2}$ Division of Marine Biology and Fisheries, Rosenstiel School of Marine and Atmospheric Science, University of Miami, 4600 \\ Rickenbacker Causeway, Miami, Florida 33149, USA \\ ${ }^{3}$ Marine Program, Wildlife Conservation Society, 2300 Southern Blvd., Bronx, New York 10460, USA \\ ${ }^{4}$ Dipartimento di Biologia Cellulare e Ambientale, Università degli Studi di Perugia, Perugia 06123, Italy
}

\begin{abstract}
The class Anthozoa is the largest metazoan group forming mutualistic symbioses with microalgae. These algal symbionts (most commonly dinoflagellates of the genus Symbiodinium) are distributed across most anthozoan orders. Records of algal cells in antipatharian (black coral) tissues have been reported, but no detailed descriptions of a mutualistic endosymbiosis exist. Here we report on zooxanthellate specimens of an unidentified black coral species within the genus Cirrhipathes that were collected from reef slopes at depths of 15 to $38 \mathrm{~m}$ in the Indonesian Archipelago. Symbionts were abundant $\left(\sim 10^{7}\right.$ symbionts $\left.\mathrm{cm}^{-2}\right)$ and ultrastructural analysis revealed the presence of a distinct symbiosome surrounding the algae, as well as algal reproduction inside the gastrodermal layer. Molecular analysis revealed the algae to be closely related to the symbionts (Symbiodinium clade G) of clionid sponges. There was also evidence for additional symbionts in clade $\mathrm{C}$ at low abundance. Taken together, these findings (high abundance, taxonomic identity, presence of symbiosome, in situ reproduction, and depth distribution) strongly suggest that these algae are functioning as mutualists. This study confirms and describes the symbiosis between Symbiodinium and a black coral species of the genus Cirrhipathes, supports the pervasiveness of mutualisms among anthozoan taxa, and highlights the diversity and flexibility of these symbiotic associations in a poorly studied group.
\end{abstract}

KEY WORDS: Symbiosis · Zooxanthellae · Cirrhipathes $\cdot$ Symbiodinium $\cdot$ Black corals $\cdot$ Coral reefs

Resale or republication not permitted without written consent of the publisher

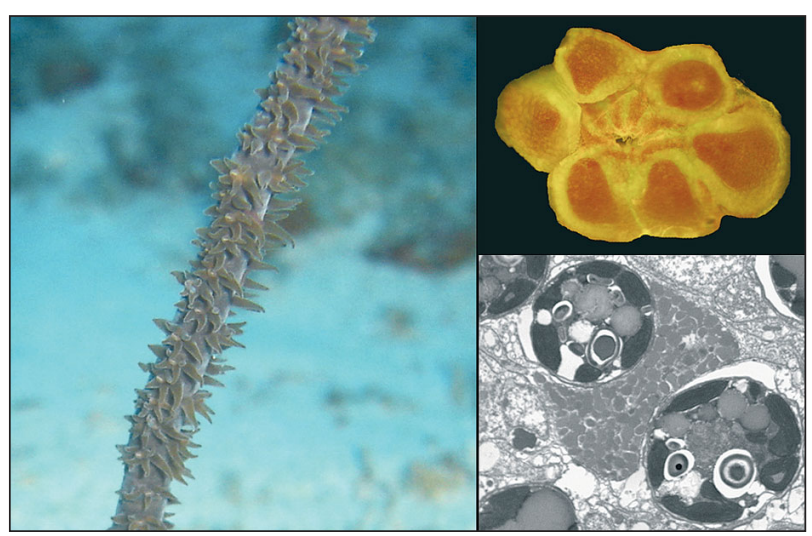

Black corals Cirrhipathes sp. (left) contain zooxanthellae (bottom right, transmission electron microscopy) inside the gastroderm (top right, red fluorescence).

Image: Marzia Bo/Elda Gaino

\section{INTRODUCTION}

Antipatharians, which are commonly known as black corals, constitute a small order ( 230 species) of colonial anthozoans found in all the oceans of the world, but particularly diverse and abundant in tropical and subtropical waters (Tazioli et al. 2007). Most of the described species are restricted to deep waters; hence, their ecology is poorly understood.

Black corals have been considered the most primitive group of hexacorallians (zoantharians) due to their simple morphological organization involving 6 tenta- 
cles, and a generally reduced muscular system which allows only partial contraction of the tentacles (van Beneden 1897, Brook 1889, von Koch 1889, van Pesch 1914, Gravier 1921). In the past, these organisms were included (together with ceriantharians) in the taxon Ceriantipatharia because of their similarity with the cerianthid larval stages 'antipathula' and 'cerinula' (van Beneden 1897, Larink \& Westheide 2006). However, recent molecular studies based on mitochondrial DNA support the Order Antipatharia as a distinct evolutionary group that is separate from the Ceriantharia (Brugler \& France 2007).

Black corals have been considered azooxanthellatea view likely resulting from the deep water $(>100 \mathrm{~m})$ location and preference for low-light conditions of most known specimens (Grigg 1965). However, records of black corals hosting algal cells are reported in the literature.

The first record of algal cells in black corals dates back to 1889, when Brook described yellowish green bodies of irregular outline within the hyaline cells of the ectoderm of Tylopathes crispa Brook, 1889. Subsequently, van Pesch (1914) listed 7 Indo-Pacific species hosting algae in their tissues, including 3 species of the genus Cirrhipathes (C. anguina [Dana, 1846], C. contorta [van Pesch, 1910] and C. spiralis var. striata [van Pesch, 1910]), 3 of the genus Stichopathes (S. gracilis [Gray, 1857], S. saccula [van Pesch, 1910], and S. variabilis [van Pesch, 1914]), and one species of dubious systematic position (Cirrhipathes [Hillopathes] ramosa [van Pesch, 1910]).

These historical reports are in partial agreement with what is currently known regarding algal symbiosis in other anthozoan groups. Algae were reported in the gastroderm of tentacles, the body wall and actinopharynx (in Cirrhipathes anguina, C. spiralis var. striata, Stichopathes gracilis, S. variabilis and S. saccula), in the ectoderm of the tentacles ( $S$. variabilis) or in the mesenteries (C. contorta and S. saccula). The algal cells, which were spherical or pear-shaped and brown or yellow-greenish in color, were generally 5 to $10 \mu \mathrm{m}$ in diameter (Brook 1889, van Pesch 1914). However, some inconsistencies concerning the localization of cells, their abundance and size, and the collection depth of the specimens did not unequivocally establish the algal cells as symbionts. For example, algal cells were found only in portions of the gastroderm, and their abundance was always low (except in C. ramosa, where numerous colorless cells were reported to be crowded together in the gastroderm of polyps). Cells were also sometimes unusually small (algal cells in the tentacles, oral cone and body wall ectoderm of $C$. anguina and $S$. gracilis were only $3 \mu \mathrm{m}$ in diameter, compared to a standard size range of $\sim 8$ to $12 \mu \mathrm{m}$ in Symbiodinium). Finally, specimens of 2 of the species were found in unusually deep waters $(\sim 560 \mathrm{~m}$ for $S$. saccula and $730 \mathrm{~m}$ for Tylopathes crispa). By modern standards, however, the information provided by Brook (1889) and van Pesch (1914) is not definitive, both in terms of the systematic description of the partners involved, and the evidence for a symbiotic relationship between them.

The only contemporary record of zooxanthellate black corals is that of Wagner et al. (2010), who reported algal cells in 10 species of Hawaiian antipatharians collected at depths of 10 to $396 \mathrm{~m}$. Dinoflagellate algae of the genus Symbiodinium were found at relatively low densities ( 0 to 92 cells $\mathrm{mm}^{-3}$ ) in the gastrodermal tissues of these corals. The great depths at which some of these specimens were collected exceeded those previously reported for zooxanthellate corals; e.g. the scleractinian Leptoseris hawaiiensis Vaughan, 1907 was found at $165 \mathrm{~m}$ at Johnston Atoll in the Pacific (Maragos \& Jokiel 1986), and a scleractinian coral collected by dredge was found at a depth of 182 to $212 \mathrm{~m}$ off Key Largo in Florida (Zahl \& McLaughlin 1959).

During a survey of the black coral communities at 2 different sites in the Indonesian Archipelago, we collected specimens of an unidentified species of Cirrhipathes hosting a large number of zooxanthellae in the gastroderm of its polyps. The purpose of this study is to report and describe a case of algal endosymbiosis in black corals using contemporary methods, namely light microscopy, scanning electron microscopy (SEM), transmission electron microscopy (TEM), and molecular techniques.

\section{MATERIALS AND METHODS}

Sample collection and preparation. Two specimens (Ment15 and Ment52) were collected by scuba divers in July 2007 at a depth of $38 \mathrm{~m}$ on the reef slopes around Siburu Island in the Mentawai Archipelago, Indonesia (15' $\left.31.67^{\prime \prime} \mathrm{S}, 99^{\circ} 36^{\prime} 8.36^{\prime \prime} \mathrm{E}\right)$. A third specimen (Indo 25) was collected in July 2008 at $15 \mathrm{~m}$ depth on the vertical wall of Siladen in the Bunaken Marine Park (137' 37.90" N, 12448' 6.32" E). Colonies were photographed in situ prior to collection, and samples of each specimen were preserved in 95\% ethanol for molecular analysis, as well as $4 \%$ formaldehyde for morphological analysis. For ultrastructural investigation, parts of each sample were fixed for $12 \mathrm{~h}$ in $2.5 \%$ glutaraldehyde buffered with filtered sea water $(\mathrm{pH}$ adjusted to 7.5 to 7.8 with $0.1 \mathrm{~N} \mathrm{NaOH}$ ), then repeatedly rinsed in the same buffer and stored at $4{ }^{\circ} \mathrm{C}$.

The morphological analysis of the black coral samples was carried out with a stereo microscope (Zeiss 
Stemi 2000C) and a light microscope (Zeiss Axioplan2). For SEM, some polyps of the formaldehyde-preserved samples were dehydrated in an ethanol series. Specimens were dried in a critical-point dryer (CPD 030 BalTec, Bal-Tec Union), mounted on stubs with silver conducting paint, sputter-coated with gold-palladium in a sputterer (Emitech K550X), and observed with an electron microscope (Philips XL30) at an accelerating voltage of $18 \mathrm{kV}$.

For TEM, 4 polyps were post-fixed for $1 \mathrm{~h}$ at $4^{\circ} \mathrm{C}$ in $1 \%$ osmium tetroxide in a buffer containing a mixture of salts commonly used for artificial sea water (final concentration of $36 \%$ ). After repeated washing in the same buffer, the material was dehydrated in a series of ethanol dilutions and embedded in an Epon-Araldite mixture. Ultrathin sections were cut on a microtome (Leica DC 300F ultracut, Leica Microsystems), collected on formvar-coated copper grids, stained with uranyl acetate and lead citrate, and examined with a TEM (Philips EM 208).

For histological investigations, $1 \mu \mathrm{m}$ sections were cut from the same blocks as those used for electron microscopy using a microtome (Leica DC 300 F ultracut, Leica Microsystems), stained with $0.5 \%$ toluidine blue, and observed with a microscope (Leica). Observations using fluorescence microscopy (Zeiss Axioskop) were conducted on entire polyps, as well as on sections embedded in cryogel and resin.

Molecular analyses. Host: Sections ( 1 cm long) of 2 of the antipatharian samples (Ment15 and Ment52) were extracted for total genomic DNA using QiagenDNeasy Blood \& Tissue Kits. Antipatharian internal transcribed spacer-1 (ITS-1), 5.8S, and internal transcribed spacer-2 (ITS-2) regions of nuclear rDNA were amplified using the forward and reverse primers of Lapian et al. (2007). PCR amplifications using Promega GoTaq Thermocycler reaction parameters were carried out as follows: initial denaturing step at $94^{\circ} \mathrm{C}$ for $3 \mathrm{~min}$, followed by 35 rounds at $94^{\circ} \mathrm{C}$ for $1 \mathrm{~min}, 50^{\circ} \mathrm{C}$ for $1 \mathrm{~min}$, and $74^{\circ} \mathrm{C}$ for $1 \mathrm{~min}$. A final extension step at $72^{\circ} \mathrm{C}$ for 7 min completed the reaction. PCR products were directly sequenced using a cycle sequencing kit (Big Dye Terminator v. 3.1) on a DNA analyzer (ABI 3730). Sequence contigs were collated using ContigExpress in Vector NTI Advance 10 (www.invitrogen.com). Consensus sequences and antipatharian sequences from Lapian et al. (2007) and Bo et al. (2009) (Accession no. AM404315 to AM404329, except AM404320) were aligned using MUSCLE (Multiple Sequence Comparison by Log-Expectation) (Edgar 2004), and the alignment edited using GeneDoc (Nicholas \& Nicholas 1997). The final alignment was trimmed to exclude the partial 18S and 28S regions on either end of the alignment, as these regions were invariant and phylogenetically uninformative.
Symbionts: The ITS-2 region of algal rDNA was amplified using the forward and reverse primers of LaJeunesse (2001), with the addition of a GC-clamp on the reverse primer for use with DGGE. PCR parameters were the same as the antipatharian parameters (see 'Molecular analyses. Host' above), except for an annealing temperature of $55^{\circ} \mathrm{C}$. DGGE gels were run using a 35 to $75 \%$ gradient. Visible bands were excised, re-amplified with the same primers (reverse primer without clamp), sequenced, and edited as described in 'Molecular analyses. Host' above. Genotypes for each sequenced band were obtained by Basic Local Alignment Search Tool (BLAST) searches in GenBank (www.ncbi.nlm.nih.gov), and named according to the Symbiodinium nomenclature of LaJeunesse (2001).

Molecular cloning. In order to confirm the identity of the ITS-2 Symbiodinium genotypes found using DGGE, and to determine their phylogenetic placement, the 5 '-end of the large subunit (LSU) rDNA was amplified using primers from Baker et al. (1997) for the D1-D2 regions. Thermocycler parameters were as described in 'Molecular analyses. Host' (annealing temperature: $55^{\circ} \mathrm{C}$ ). Amplified products were digested with the restriction enzymes TaqI and HhaI, and restriction fragment length polymorphisms (RFLPs) screened on $3.5 \%$ agarose gels. Amplified products were also were excised, re-amplified, and cloned in bacterial vectors using pGEM-T Easy Vector Systems (Promega) following manufacturer protocols. Successfully transformed and cloned bacterial colonies were used as template DNA for PCR by picking the plated bacterial colony with a pipette tip and inserting it into a PCRready reaction. M13 primers (M13F-TGT AAA ACG ACG GCC AGT and M13R-CAG GAA ACA GCT ATG $A C C)$, which flanked the insertion region of the vector, were used to amplify the cloned inserts. PCR products were sequenced as described in 'Molecular analyses. Host' and assembled using Geneious Pro 4.5.4 (Drummond et al. 2008). Only contigs with unambiguous base calls were used for phylogenetic analyses. Sequences were aligned to the LSU rDNA sequences of clades A-I of Schönberg \& Loh (2005), Pochon et al. (2006), Schönberg et al. (2008), and Pochon \& Gates (2010), using methods described in 'Molecular analyses. Host'. Alignment ends were trimmed to the length of the cloned LSU rDNA sequences. Sequences retrieved from GenBank that were shorter than the cloned sequences were not used, as their use would require trimming of the final alignment and result in loss of phylogenetic information.

Phylogenetic reconstruction. Phylogenetic analyses for the antipatharian ITS-1, 5.8S, and ITS-2 alignment were performed using Bayesian maximum likelihood (MB) in MrBayes v3.1.2 (Huelsenbeck \& Ronquist 
2001), maximum likelihood (ML) in PhyML (Guindon \& Gascuel 2003), and maximum parsimony (MP) and minimum evolution (ME) in PAUP* v4.0b10 (Swofford 2002). Phylogenies for the algal LSU rDNA alignment were constructed using MrBayes and PhyML.

ModelTest (Posada \& Crandall 1998) using AIC (Akaike's Information Criterion) found the nucleotide model of evolution HKY+I (HKY = variable base frequencies, variable transition and transversion frequencies; $\mathrm{I}=$ extent of static, unchanging sites) (base freq: $\mathrm{A}=0.3201, \mathrm{C}=0.2135, \mathrm{G}=0.1906, \mathrm{~T}=0.2758$; nst $=2$; rates $=$ equal $_{i}$ Tratio $=0.7973$; Pinvar $=0.7546$ ) to best fit the antipatharian alignment and was used for ML and ME (distance measure $=\mathrm{HKY}$ ) analyses. For algal sequences, the model TIM+G (TIM = variable base frequencies, variable transitions, transversions equal; $\mathrm{G}=$ gamma distributed site-to-site rate variation) (base freq: $\mathrm{A}=0.22295, \mathrm{C}=0.2003, \mathrm{G}=$ $0.2899, \mathrm{~T}=0.2804 ;$ rates $=$ gamma; shape $=0.5160$ ) was used for ML. MP was performed with branch swapping set to TBR (tree bisection-reconnection) and starting trees obtained via stepwise addition (random, 100 replicates). Statistical support for branching topologies was generated by 1000 bootstrap replicates for MP, ME, and ML for the antipatharians and 1000 replicates for ML for Symbiodinium. MB for both antipatharians and algae was run with the likelihood parameters that matched their respective models chosen in ModelTest, HKY+I (nst $=2$, rates = propinv) and $\mathrm{TIM}+\mathrm{G}$ (nst $=6$, rates = gamma) models, with default priors. Tree space was explored using 4 Markov chains for 1000000 generations, with trees being sampled every 100 generations. Posterior probabilities were calculated by setting the burn-in to 2500 ( $25 \%$ of total trees sampled), and values were calculated using the remaining 7500 trees. To root the phylogenetic trees, the scleractinian coral Pavona cactus (Forskål, 1775) (accession no. EU233631) was used for the antipatharians, while the dinoflagellate Protodinium simplex (Lohmann 1908) (EF205014) was used for Symbiodinium. These outgroups were chosen because they represent taxa that are phylogenetically related to the ingroup, but are more distantly related to each ingroup member than any of the ingroup members are to each other.

\section{RESULTS}

\section{Morphology of black coral specimens}

Based on traditional morphological characters, all 3 specimens belong to the same unidentified species in the genus Cirrhipathes, and are characterized by unbranched, unpinnulated colonies, and by polyps that are irregularly arranged around the stem. The colonies of the symbiotic specimens have a 0.5 to $1.5 \mathrm{~m}$ long straight corallum. In the longest specimens, the corallum is slightly coiled at the apex (Fig. 1A). The polyps are large ( 1 to $1.5 \mathrm{~mm}$ in transverse diameter, interpolypar distance 0.5 to $1.1 \mathrm{~mm}$ ) with a prominent oral cone $(0.3 \mathrm{~mm}$ high). Sagittal tentacles are slightly longer than the laterals, and are 1 to $4 \mathrm{~mm}$ long, but their length varies greatly depending on contraction state (minimum 0.6 to $0.7 \mathrm{~mm}$ long). A white transparent ectoderm over a gastrodermal layer of yellowbrown zooxanthellae contributes to an overall velvety appearance (Fig. 1B,D). The long tentacles are characterized by circular spots of cnidocysts that are uniformly distributed over their surface (Fig. 1D,E). The cnidome is similar among the 3 analyzed specimens: spirocysts $(15 \times 2 \mu \mathrm{m})$, basitrich isorhizae (20 to $25 \times$ $3 \mu \mathrm{m})$ and mastigophores $(15 \times 5 \mu \mathrm{m})$. The spines $(250$ to $300 \mu \mathrm{m}$ high, $120 \mu \mathrm{m}$ wide and 350 to $400 \mu \mathrm{m}$ apart) are arranged in 6 to 8 longitudinal rows, are equal in shape along the entire length of the stem and on both sides of it, and are triangular, with a smooth or slightly papillose surface (Fig. 1F).

Sections examined using fluorescence microscopy provided evidence for the localization of the zooxanthellae inside the gastroderm of the tentacles (Fig. 1G), and in the gastroderm of the gastric cavity (Fig. 1H). Fractured polyps observed under SEM showed that algal cells were evenly distributed in rows even down the length of the stem (Fig. 1I-K).

\section{Morphology of zooxanthellae}

Histological sections of the polyps confirmed the presence of numerous zooxanthellae in the gastroderm

Fig. 1. Zooxanthellate Cirrhipathes sp. (A) Underwater photograph of an entire whip specimen. (B) Close-up view of a portion of the colony with extended polyps. (C) Underwater photograph showing the characteristic velvety appearance of living polyps. (D) Scanning electron microscope (SEM) image of a polyp showing the uniform distribution of cnidocysts organized in circular patches on the ectoderm of the tentacles. (E) Magnified ectodermic cnidocyst spots. (F) SEM image of the simple triangular spines. (G) Gastrodermal localization of algal symbionts in a tentacle. (H) Fluorescence of zooxanthellae in an entire polyp. The symbiont-free epidermal layer and the radial distribution of zooxanthellae in the oral cone, corresponding to the mesenteries, are clearly evident. (I) SEM image of a longitudinal section of the oral cone showing a battery of spirocysts in the ectoderm and various zooxanthellae cells in the gastroderm. (J, K) SEM images of the algal cells within the cnidarian gastrodermic tissue. Scale bars: $A=10 \mathrm{~cm} ; \mathrm{B}, \mathrm{C}=2 \mathrm{~mm} ; \mathrm{D}, \mathrm{F}, \mathrm{H}=1 \mathrm{~mm} ; \mathrm{E}, \mathrm{G}=100 \mu \mathrm{m} ; \mathrm{J}, \mathrm{K}=20 \mu \mathrm{m} ; \mathrm{I}=10 \mu \mathrm{m}$ 

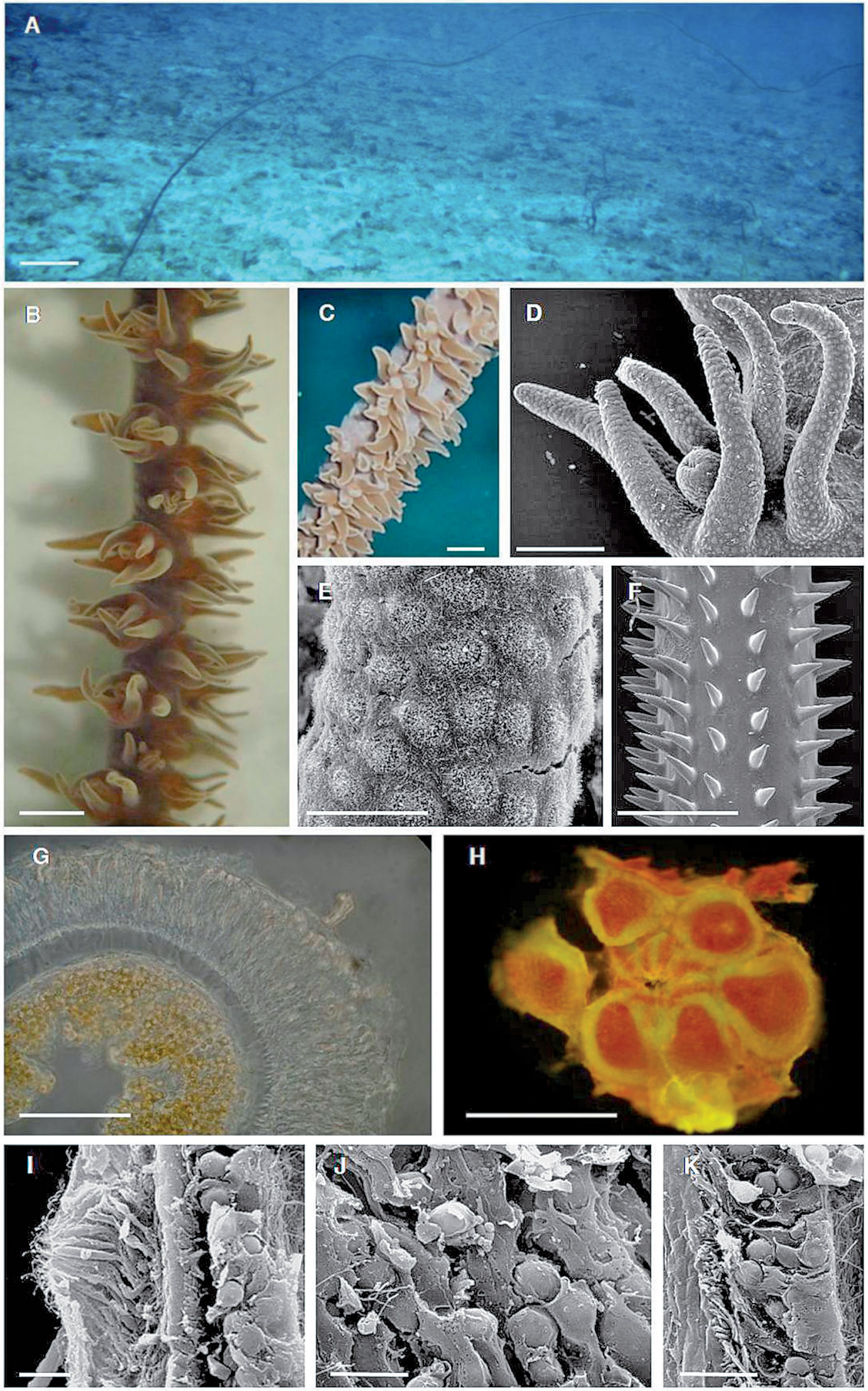

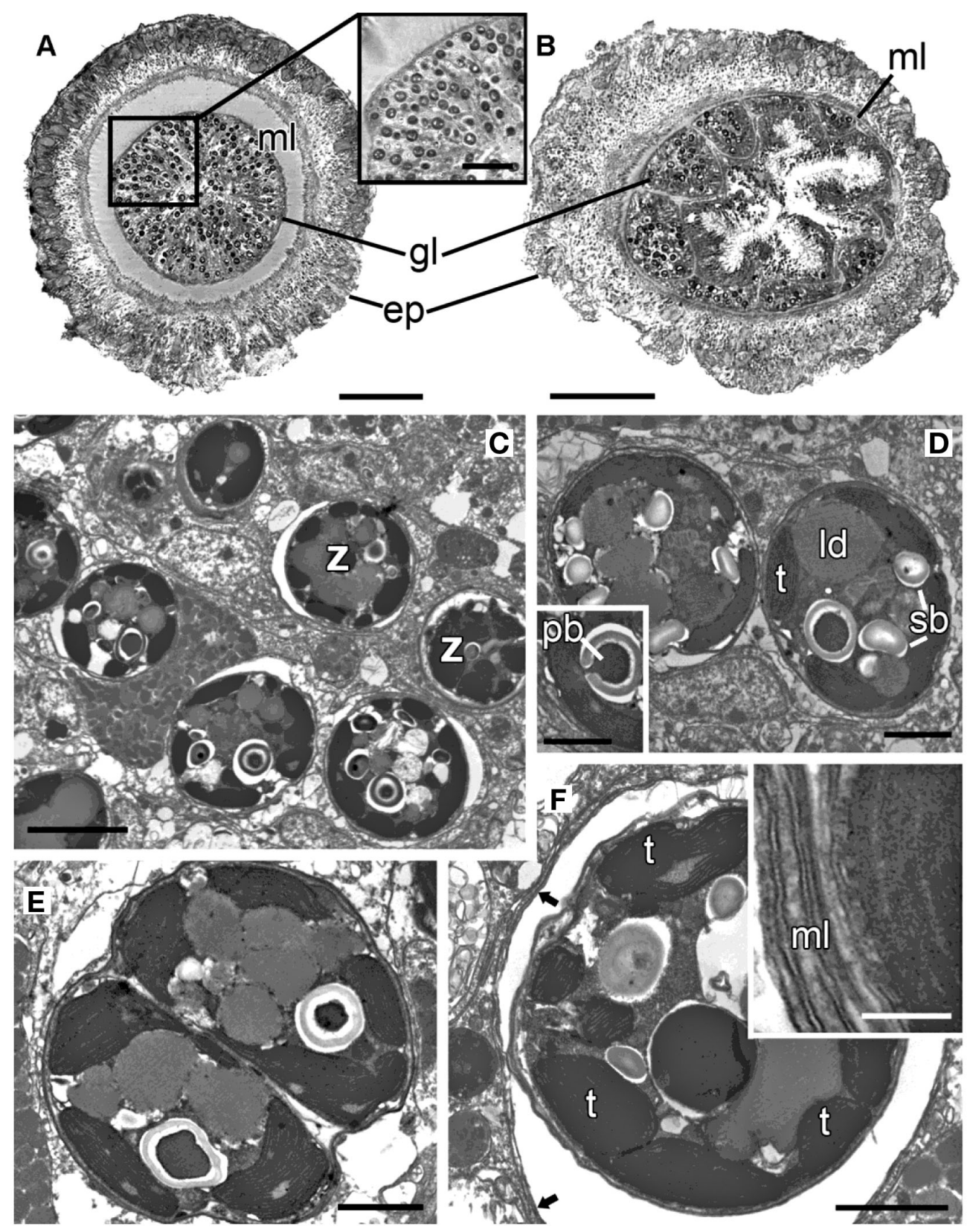

Fig. 2. Cirrhipathes sp. Sections of zooxanthellate antipatharian polyps. (A) Semithin section revealing the location of the algal cells inside the gastroderm (gl) of a tentacle. Inset is a magnified view showing the even arrangement of algal cells inside the tissue. ep: epidermal layer; ml: mesogleal layer. (B) Semithin section revealing the location of the zooxanthellae inside the gastroderm of the mesenteries of the oral cone. (C) Ultrastructural evidence of a cluster of zooxanthellae (z) living in the gastroderm. (D) Fine organization of zooxanthellae showing: starch bodies (sb), lipid droplets (ld), and peripheral thylakoids (t). Inset: detailed pyrenoid body (pb). (E) Transmission electron microscope (TEM) view of mitotic cells inside the same vacuole. (F) Ultrastructural view of some thylakoids (t). Note the host-derived symbiosome membrane (arrows) delimiting the peri-algal vacuole. Inset: multiple layers (ml) of the symbiotic zooxanthellae. Scale bars: $A, B=100 \mu m_{;}$A inset $=30 \mu m_{;}, D, D$ inset, $E, F=2 \mu m_{;}$F inset $=250 \mathrm{~nm}$

of the tentacles (Fig. 2A, and inset) and in the gastroderm of the mesenteries of the oral cone (Fig. 2B). In both cases, these algal cells were evenly arranged inside the tissue, where they were easily distinguishable by their uniform, spherical, and compact shape. In sections for ultrastructural analysis, zooxanthellae were clearly visible inside discrete cell vacuoles and were distributed in rows in the gastrodermal tissue (Fig. 2C). All vacuoles were delimited by a symbiosome membrane (Fig. 2F) (Wakefield et al. 2001), which separated the symbionts from the cytoplasm of the host cells. Algal cells measured 5 to $7 \mu \mathrm{m}$ in dia- 
meter, and were present at a density of $\sim 10^{7}$ cells $\mathrm{cm}^{-2}$, including those distributed in the interpolypar coenenchyme. They showed the typical characteristics of symbiotic dinoflagellates: peripheral thylakoids formed by a series of superimposed dark lamellae (Fig. 2F, inset); a large rounded accumulation body or lipid body (Fig. 2D); and a pyrenoid body surrounded by a layer of starch grains (Fig. 2D, inset). Some images revealed the occurrence of 2 algal cells inside the same vacuole $-\mathrm{a}$ feature consistent with a mitotic division phase (Fig. 2E).

\section{Phylogenetic reconstruction of studied antipatharians}

Phylogenetic reconstruction resulted in a tree topology similar to that shown by Lapian et al. (2007) and Bo et al. (2009) (Fig. 3). The 2 zooxanthellate antipatharians (Ment15 and Ment53) grouped monophyletically, and fell within a large clade (well supported by MP, less well supported by MB, ML and $\mathrm{ME}$ ) that contained 6 of the 7 members analyzed from the family Antipathidae, and 1 of the 3 members of the Aphanipathidae, Rhipidipathes reticulata (Esper, 1795). Ment15 and Ment53 grouped as a sister clade to $R$. reticulata in all reconstruction methodologies, except $\mathrm{MB}$, with reasonable statistical support (ML 72, MP 80, ME 92); and the Ment15-Ment53- $R$. reticulata clade was a sister clade to a large Antipathidae clade (excluding Pseudocirrhipathes mapia Bo \& Bavestrello, 2009).

All analyzed members of the family Myriopathidae formed a monophyletic clade that is well supported by all reconstruction methodologies. The remaining 2 species belonging to the family Aphanipathidae, Phanopathes rigida (Pourtalès, 1880) and Aphanipathes cf. sarothamnoides Brook, 1889, grouped together. However, the family remained polyphyletic with respect to the other member of the family, Rhipidipathes reticulata. Specimens of Pseudocirrhipathes mapia did not group with the other members of the family Antipathidae, but formed a weakly supported sister clade to a large clade that contains the Myriopathidae clade, and $P$. rigida together with $A$. cf. sarothamnoides as subclades.

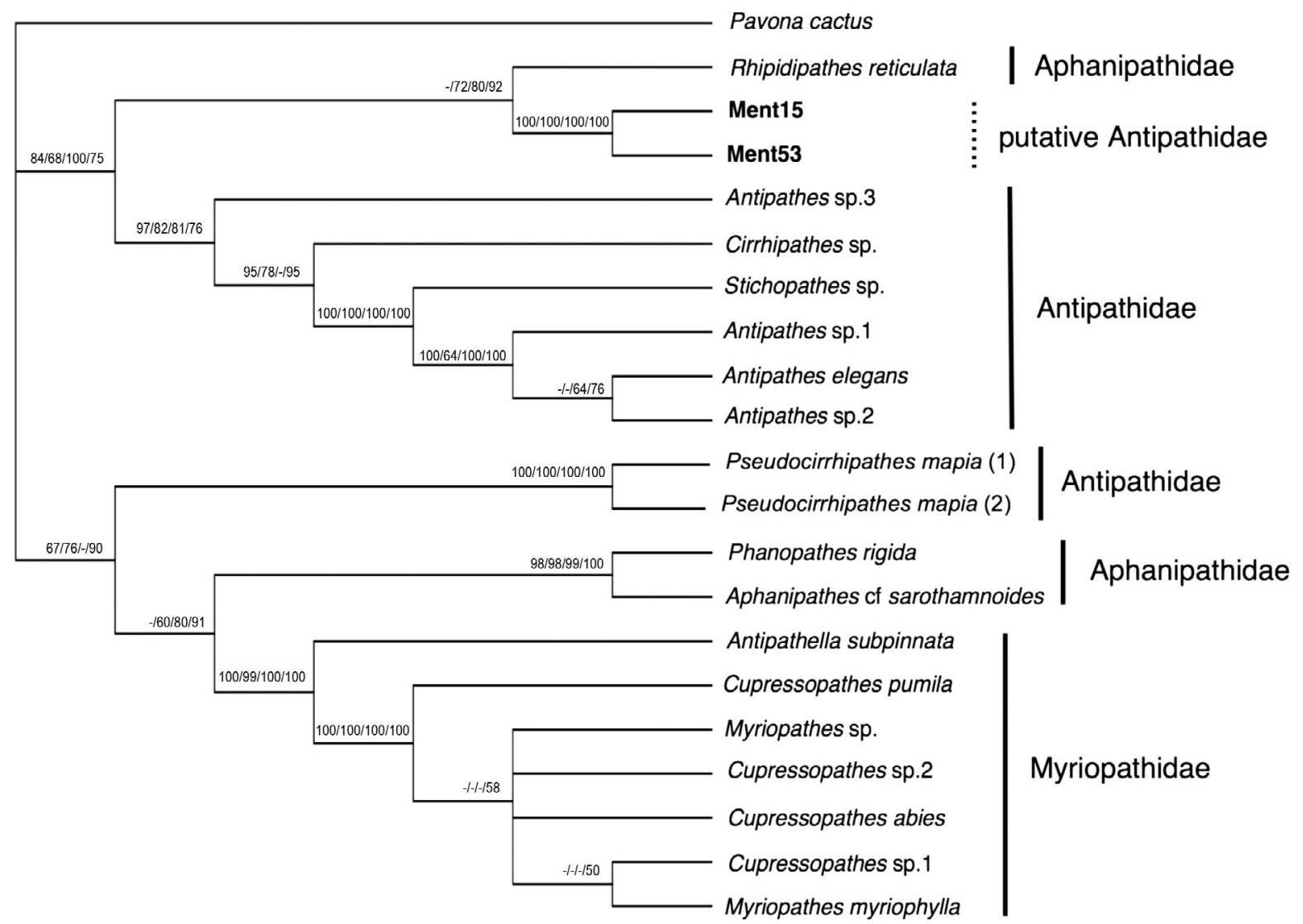

Fig. 3. Cladogram showing supported clades for Bayesian maximum likelihood, maximum likelihood, maximum parsimony and minimum evolution methods that have at least one reconstruction method supported with a bootstrap value or posterior probability $>50$ (values shown on branch nodes, respectively). Branch lengths do not represent distances. Bold: zooxanthellate black coral samples. Vertical lines: taxa grouped at the family level. Dotted line: uncertain systematic placement of samples Ment15 and Ment53 


\section{Molecular and phylogenetic analysis of Symbiodinium}

DGGE analysis of both zooxanthellate black coral samples (Ment15 and Ment53) produced a band profile with one dominant band flanked by fainter secondary bands (Fig. 4). Sequence analysis in BLAST revealed the dominant band to be $95 \%(286 / 300 \mathrm{bp})$ similar to G3 (accession no. AM748600). Of the secondary bands, one was found to be $99 \%$ (1 bp difference) similar to $\mathrm{C} 15$ ( $\mathrm{C} \rightarrow \mathrm{T}$ at position 31 ) and $\mathrm{C} 4$ (insertion of $\mathrm{T}$ at position 245). The amount of clade $\mathrm{G}$ relative to clade $\mathrm{C}$ appeared to be greater based on the former's darker band intensity, although this is only weak evidence for greater abundance of symbiont clade $\mathrm{G}$ relative to clade $\mathrm{C}$. The other faint secondary bands did not produce clean sequences usable for contig assembly.

Cloning of LSU rDNA produced sequences that closely matched those of members of clade G Symbiodinium. RFLP analysis revealed a single profile with both TaqI and HhaI (Fig. 5) that matched the profile predicted from the clade G LSU sequences. Phylo-

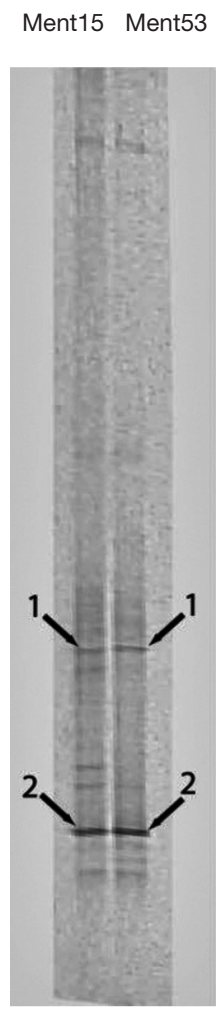

Fig. 4. DGGE analysis of internal transcribed spacer ITS-2 rDNA showing characteristic profile for Symbiodinium found in black coral samples Ment15 and Ment53. The dominant band (2) was a $95 \%$ match to G3. The secondary band (1) was a $99 \%$ match to C15 and C4 (see text for details). All other secondary bands did not sequence cleanly for accurate contig assemblies genetic reconstruction (Fig. 6) of the LSU rDNA sequences placed all sequences from both black coral samples, as well as the clionid sponge symbiont sequences, in a well-supported clade, using both $\mathrm{MB}$ and ML (although bootstrap support was low with ML). The remaining tree topology was similar to that of Pochon et al. (2004, 2006), Schönberg \& Loh (2005), and Pochon \& Gates (2010).

\section{DISCUSSION}

In cnidarians, symbiotic relationships with zooxanthellae of the genus Symbiodinium have been recorded in the classes Hydrozoa, Scyphozoa, and Anthozoa (Baker 2003). Among anthozoans in particular, the phenomenon is exceptionally widespread, both in octocorals (alcyonarians) and hexacorals. The subclass Hexacorallia (Zoantharia) includes many zooxanthellate cnidarians in the Scleractinia, Actinaria, Corallimorpharia, and Zoanthidea (Stat et al. 2006). Until recently (Wagner et al. 2010), however, antipatharians (like ceriantharians) were traditionally considered to be azooxanthellate hexacorallians, probably as a result of various factors such as the distribution of many of these organisms in deep water. Wagner et al. (2010) reported low densities of Symbiodinium in several Hawaiian deep-water antipatharians, in agreement with historical reports of sparse algal cells in some black corals (Brook 1889, van Pesch 1914). Low and
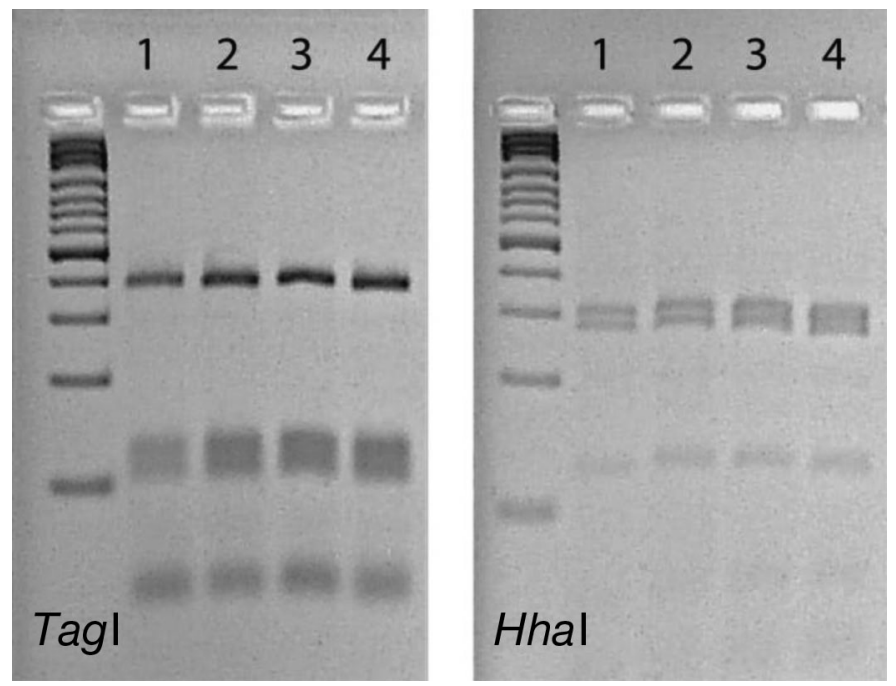

Fig. 5. Restriction fragment length polymorphisms (RFLPs) in Symbiodinium large subunit rDNA, using the enzymes TaqI (left image) and HhaI (right image). Each sample was independently amplified and digested twice. Lane 1: Ment15, Lane 2: Ment53; Lane 3: Ment15, Lane 4: Ment53. Left lane for each image is $100 \mathrm{bp}$ size standard. Only one RFLP genotype (corresponding to a Symbiodinium in clade $\mathrm{G}$ ) is detectable in each sample 


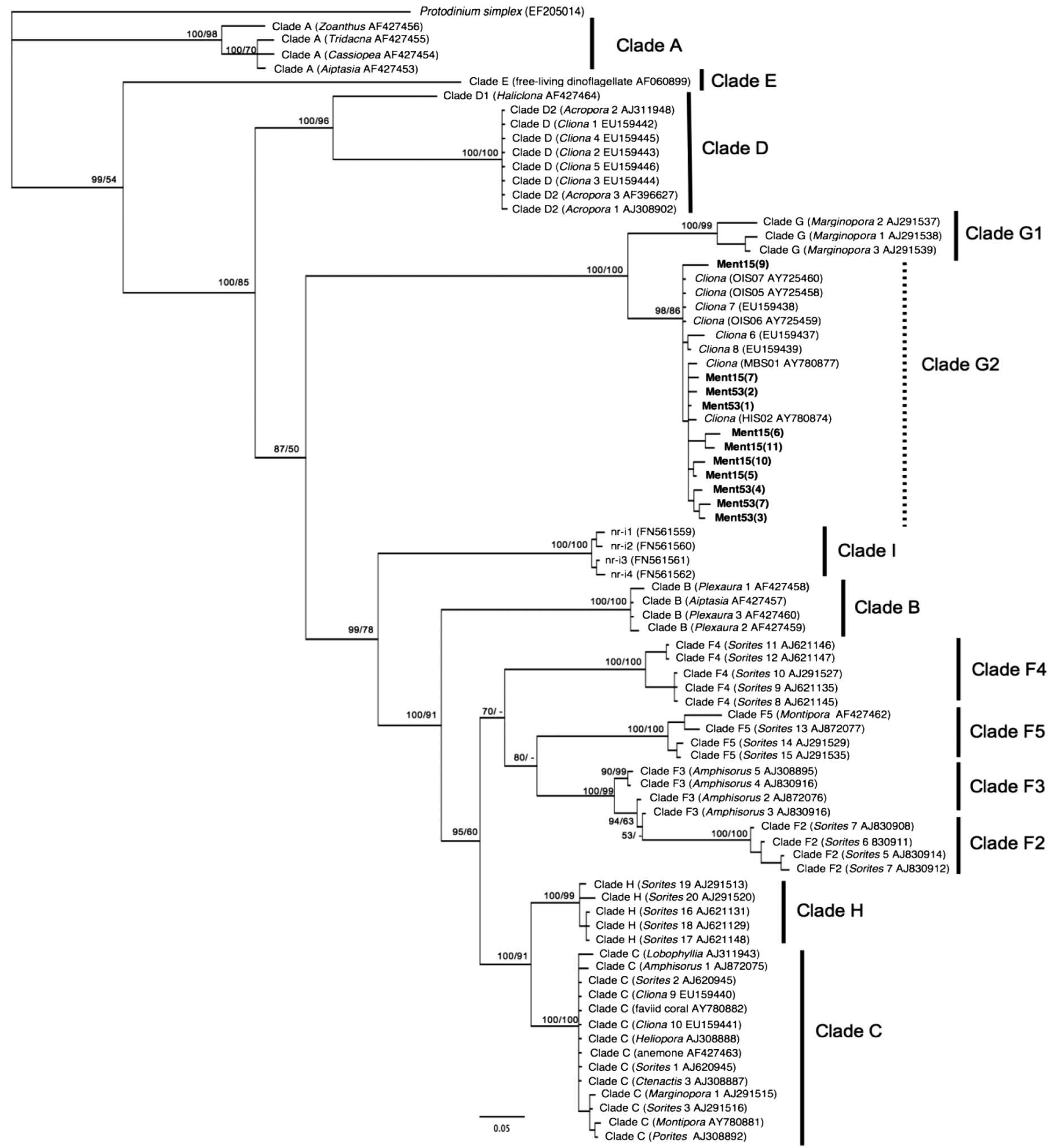

Fig. 6. Bayesian phylogram showing placement of algal symbionts in black coral samples Ment15 and Ment53 (in bold) among the representative Symbiodinium clades A-I using partial large subunit rDNA sequences. Bayesian posterior probabilities and maximum likelihood (ML) bootstrap replicates (1000 reps) are shown on branch nodes, respectively. Values $<50$ are shown as ' - '.

Taxa include the name of Symbiodinium clade, and their host and GenBank accession number in parentheses 
variable cell densities suggest that some species may follow a potentially mixotrophic lifestyle involving facultative algal symbiosis that may be dependent on location and environment. These factors have probably led to an underestimation of algal symbiosis in antipatharians in general.

If we consider all literature records of zooxanthellate black coral species, then algal symbionts are evenly distributed in both whip (10 species: 5 Cirrhipathes and 5 Stichopathes) and branched (7 species: 2 Antipathes, 1 Aphanipathes, 2 Myriopathes, 1 Acanthopathes, 1 Bathypathes) antipatharians (4 out of 7 antipatharian families). However, this is the first report that provides multiple lines of evidence supporting a genuinely mutualistic symbiotic relationship, and it involves just one species in the genus Cirrhipathes. The observations of Brook (1889) and van Pesch (1914), although historically significant, have not been corroborated by sufficient evidence to support, by contemporary standards, the existence of a symbiotic relationship. Similarly, Wagner et al. (2010), while greatly expanding our appreciation for algal diversity in a variety of antipatharians, indicated that the available evidence (low cell densities, extreme depths) suggested that the algae might be involved in parasitic rather than mutualistic symbiosis. Our specimens contained very high densities of zooxanthellae inside the gastroderm of both tentacles and gastric cavities, and their organizational pattern, as well as the presence of mitotic algal cells inside the same vacuole, suggests that these cells are capable of reproducing inside their host. The occurrence of a membrane layer delimiting the zooxanthellae is also interpreted as indicating an endosymbiotic association with these black corals. These membranes are typical of cnidarian-dinoflagellate symbiosis, and the use of monoclonal antibodies has shown that these membranes are symbiont-derived and are not present when symbionts are maintained in culture (Wakefield et al. 2001).

We found evidence for symbionts in 2 clades of Symbiodinium in the black coral samples. However, the DGGE bands from which C15-like and C4-like ITS-2 sequences were recovered were faint, no RFLP profiles corresponding to clade $\mathrm{C}$ were observed, and no Csequences were recovered from cloning of LSU rDNA. Consequently, we conclude that the dominant symbionts of this antipatharian are very similar to the symbionts in clade $\mathrm{G}$ found in clionid sponges (Schönberg \& Loh 2005, Granados et al. 2008). It is possible that the $\mathrm{C}$-sequences we retrieved using DGGE represent symbionts which are preferentially amplified by ITS-2 primers and are thus detectable by DGGE, but which are too rare to be picked up by the cloning methodology used here for LSU rDNA. These findings are in contrast to Wagner et al. (2010), who found that Hawai- ian black corals hosted members of clade C Symbiodinium, including some types found in Hawaiian zooxanthellate scleractinian corals. Our Indonesian Cirrhipathes sp. hosts members of clade G Symbiodinium that are very different from those found in scleractinian corals worldwide (Baker 2003, but see LaJeunesse et al. 2010 for a report of some scleractinians in intertidal environments in Thailand hosting members of clade G).

The unusual symbionts that dominate these black corals, and which are also found in some sponges, are most closely related to (but distinct from) the Symbiodinium in clade $\mathrm{G}$ that have been found in some foraminiferans (genus Marginopora) (Pochon et al. 2001). We have differentiated these 2 groups within clade $G$ by referring to the symbionts initially described from Foraminifera as members of subclade G1, and the symbionts of black corals and clionid sponges as members of a distinct subclade G2 (Fig. 6). This follows the precedent of Pochon et al. (2001) and Pochon et al. (2006), who introduced numerical subclades for Symbiodinium clades $\mathrm{F}$ and $\mathrm{D}$, respectively.

The purpose of the present study is to report and describe, using contemporary methods, a case of algal endosymbiosis in black corals. In some cases, the presence of zooxanthellae has been used as a taxonomic character for the description of new cnidarian species (e.g. Marques et al. 2000). However, we have chosen not to formally describe a new species of Cirrhipathes here due to the complex and unresolved taxonomy of the whip black coral taxa. Moreover, although the morphological characters of our specimens clearly support their inclusion in the genus Cirrhipathes, the molecular analyses indicate that they do not belong to the Cirrhipathes clade of Lapian et al. (2007) and Bo et al. (2009) (Fig. 3).

In conclusion, these findings (high abundance, taxonomic identity, presence of symbiosome, in situ reproduction, and depth distribution) strongly suggest that these algae are functioning as mutualists. The present study documents the symbiosis between Symbiodinium of the subclade G2 and a black coral species of the genus Cirrhipathes, supports the pervasiveness of mutualisms among anthozoan taxa, and highlights the diversity and flexibility of these symbiotic associations in a poorly studied group.

Acknowledgements. We thank C. De Eguilior (PharmaMar S.p.A) for the organization of the expedition in Mentawai, and P. Jones (University of Miami) for assistance with the Symbiodinium analyses. A.C.B. was supported by a grant from the US National Science Foundation (BIO OCE 0527184), the Lenfest Ocean Program, and the Tiffany \& Co. Foundation. H.H.W. was also supported by a Rowlands Fellowship and a Knight Fellowship from the University of Miami. 


\section{LITERATURE CITED}

Baker AC (2003) Flexibility and specificity in coral-algal symbiosis: diversity, ecology and biogeography of Symbiodinium. Annu Rev Ecol Syst 34:661-689

Baker AC, Rowan R, Knowlton N (1997) Symbiosis ecology of two Caribbean acroporid corals. Proc 8th Int Coral Reef Symp, Panama 2:1295-1300

Bo M, Barucca M, Biscotti MA, Canapa A, Lapian HFN, Olmo E, Bavestrello G (2009) Description of Pseudocirrhipathes (Cnidaria: Anthozoa: Hexacorallia: Antipathidae), a new genus of whip black corals from Celebes Sea. Ital J Zool 76:392-402

Brook G (1889) Report on the Antipatharia collected by H. M. S. Challenger during the years 1873-1876. Rep Sci Res Voy Chall 32:222

Brugler MR, France S (2007) The complete mitochondrial genome of the black coral Chrysopathes formosa (Cnidaria: Anthozoa: Antipatharia) supports classification of antipatharians within the subclass Hexacorallia. Mol Phylogenet Evol 42:776-788

Drummond AJ, Ashton B, Cheung M, Heled J and others (2008) Geneious v4.0, available at www.geneious.com/

Edgar RC (2004) MUSCLE: multiple sequence alignment with improved accuracy and speed. Proc 2004 IEEE Computational Systems Bioinformatics Conf, IEEE Computer Society, Washington, DC, p 728-729

Granados C, Camargo C, Zea S, Sanchez JA (2008) Phylogenetic relationships among zooxanthellae (Symbiodinium) associated to excavating sponges (Cliona spp.) reveal an unexpected lineage in the Caribbean. Mol Phylogenet Evol 49:554-560

Gravier Ch (1921) Antipathaires provenant des Campagnes des yachts Princess-Alice et Hirondelle II (1903-1913). Rés Camp Sci Monaco 59:20

Grigg RW (1965) Ecological studies of black coral in Hawaii. Pac Sci 19:244-260

Guindon S, Gascuel O (2003) A simple, fast, and accurate algorithm to estimate large phylogenies by maximum likelihood. Syst Biol 52:696-704

Huelsenbeck JP, Ronquist R (2001) MrBayes: Bayesian inference of phylogeny. Bioinformatics 17:754-755

$>$ LaJeunesse TC (2001) Investigating the biodiversity, ecology and phylogeny of endosymbiotic dinoflagellates in the genus Symbiodinium using the ITS region: in search of a 'species' level marker. J Phycol 37:866-880

LaJeunesse TC, Pettay DT, Sampayo EM, Phongsuwan N and others (2010) Long-standing environmental conditions, geographic isolation and host-symbiont specificity influence the relative ecological dominance and genetic diversification of coral endosymbionts in the genus Symbiodinium. J Biogeogr 37:785-800

Lapian HFN, Barucca M, Bavestrello G, Biscotti MA and others (2007) A systematic study of some black corals species (Antipatharia, Hexacorallia) based on rDNA internal transcribed spacers sequences. Mar Biol 151:785-792

Larink O, Westheide W (2006) Coastal plankton. Photo guide for European seas. Wiltshire KH, Boersma M (eds) AWI handbooks on marine flora and fauna. Verlag Dr. Friedrich Pfeil, Munich

Editorial responsibility: Tim McClanahan, Mombasa, Kenya
Maragos JE, Jokiel PL (1986) Reef corals of Johnston Atoll: one of the world's most isolated reefs. Coral Reefs 4: $141-150$

> Marques AC, Peña Cantero AL, Vervoort W (2000) Mediterranean species of Eudendrium Ehrenberg, 1834 (Hydrozoa, Anthomedusae, Eudendriidae) with the description of a new species. J Zool (Lond) 252:197-213

Nicholas KB, Nicholas HB (1997) GeneDoc: a tool for editing and annotating multiple sequence alignments, available at www.nrbsc.org/gfx/genedoc/

> Pochon X, Gates RD (2010) A new Symbiodinium clade (Dinophyceae) from soritid Foraminifera in Hawai'i. Mol Phylogenet Evol 56:492-497

Pochon X, Pawlowski J, Zaninetti L, Rowan R (2001) High genetic diversity and relative specificity among Symbiodinium-like endosymbiotic dinoflagellates in soritid foraminiferans. Mar Biol 139:1069-1078

Pochon X, LaJeunesse TC, Pawlowski J (2004) Biogeographic partitioning and host specialization among foraminiferan dinoflagellate symbionts (Symbiodinium; Dinophyta). Mar Biol 146:17-27

Pochon X, Montoya-Burgos JI, Stadelmann B, Pawlowski J (2006) Molecular phylogeny, evolutionary rates, and divergence timing of the symbiotic dinoflagellate genus Symbiodinium. Mol Phylogenet Evol 38:20-30

Posada D, Crandall KA (1998) Modeltest: testing the model of DNA substitution. Bioinform 14:817-818

Schönberg CHL, Loh WKW (2005) Molecular identity of the unique symbiotic dinoflagellates found in the bioeroding demosponge Cliona orientalis. Mar Ecol Prog Ser 299: $157-166$

Schönberg CHL, Suwa R, Hidaka M, Loh WKW (2008) Sponge and coral zooxanthellae in heat and light: preliminary results of photochemical efficiency monitored with pulse amplitude modulated fluorometry. Mar Ecol 29: $247-258$

Stat M, Carter D, Hoegh-Guldberg O (2006) The evolutionary history of Symbiodinium and scleractinian hosts: symbiosis, diversity, and the effect of climate change. Perspect Plant Ecol Evol Syst 8:23-43

Swofford DL (2002) PAUP* . Phylogenetic analysis using parsimony ( ${ }^{*}$ and other methods), version $4.0 \mathrm{~b} 10$. Sinauer, Sunderland, MA

Tazioli S, Bo M, Boyer M, Rotinsulu H, Bavestrello G (2007) Ecological observations of some common antipatharian corals in the Marine Park of Bunaken (North Sulawesi, Indonesia). Zool Stud 46:227-241

van Beneden E (1897) Les Anthozoaires de la 'PlanktonExpedition' (Die Anthozoen der Plankton-Expedition). Ergeb Plank Exp Humboldt 2:222

van Pesch AJ (1914) The Antipatharia of the Siboga expedition. Siboga Exp 17:258

von Koch G (1889) Die Antipathiden des Golfes von Neapel. Mitt Zool Stat Neapel 9:187-204

> Wagner D, Pochon X, Irwin L, Toonen RJ, Gates RD (2010) Azooxanthellate? Most Hawaiian black corals contain Symbiodinium. Proc Biol Sci. doi:10.1098/rspb.2010.1681

Zahl PA, McLaughlin JJA (1959) Studies in marine biology. IV. On the role of algal cells in the tissues of marine invertebrates. J Protozool 6:344-352

Submitted: October 11, 2010; Accepted: May 24, 2011

Proofs received from author(s): July 14, 2011 